\title{
DISKURSUS DERADIKALISASI AGAMA: Pola Resistensi Pesantren terhadap Gerakan Radikal
}

\author{
Hasyim Muhammad, Khoirul Anwar, Misbah Zulfa E. \\ Universitas Islam Negeri (UIN) Walisongo Semarang \\ e-mail: hasyimmuhammad@ymail.com
}

\begin{abstract}
Pesantren had a specific perspective related to religious radicalism and violence. The purpose of this study is to uncover the discourse of radicalism and deradicalization in Pesantren Soko Tunggal Semarang. Applying the qualitative research, it was revealed that Pesantren Soko Tunggal against all forms of violence in the name of religion. According to Pesantren Soko Tunggal radical movements in the name of religion is a form of misunderstanding of the religion. Islamic radicalism is generally based on the Wahhabi's understanding, so that attitudes and behavior are influenced by the teachings of Wahhabi. In the view of Wahabism heresy in religion is a form of desecration and denial that must be fought. Pesantren assumed that Pancasila and UUD 1945 is a form of actual enforcement of Islamic law due to Pesantren Soko Tunggal kept to preserve the values of moderatism and develop a peaceful multicultural life.
\end{abstract}

$* * *$

Pesantren memiliki perspektif tersendiri terhadap radikalisme agama dan kekerasan. Penelitian ini bertujuan untuk mengungkap wacana radikalisme dan deradikalisasi di Pesantren Soko Tunggal Semarang. Dengan menggunakan pendekatan kualitatif penelitian menunjukkan bahwa Pesantren Soko Tunggal menentang segala bentuk kekerasan atas nama agama. Dalam pandangan Pesantren Soko Tunggal bahwa gerakan radikal atas nama agama merupakan bentuk kesalahpahaman agama. Islam radikal umumnya didasarkan pada pemahaman Wahabi, sehingga sikap dan perilaku dipengaruhi oleh Wahabi. Menurut Wahabi, bid'ah dalam agama adalah bentuk penodaan dan penolakan yang harus diperangi. Pesantren menganggap bahwa Pancasila dan UUD 1945 merupakan bentuk penegakan hukum Islam yang aktual. Karena di Pesantren Soko Tunggal ini ingin mempertahankan nilai-nilai moderatisme dan mengembangkan kehidupan multikultural yang damai.

Keywords: Pesantren Soko Tunggal, moderatisme, diskursus radikalisme, deradikalisasi

Walisongo, Volume 23, Nomor 1, Mei 2015 


\section{A. Pendahuluan}

Fenomena radikalisme yang mengatasnamakan agama di Indonesia menjadi perhatian serius dari berbagai elemen. Reaksi atas kemunculan Islam radikal ini berhasil membuat fenomena tersebut harus diperhatikan dan direnungkan bersama. Sebab apabila gerakan Islam radikal ini dibiarkan tumbuh kembang, maka akan berdampak lebih besar terhadap kerukunan umat beragama, terlebih dengan kondisi bangsa Indonesia yang kaya akan keberagaman.

Radikalisme agama merupakan fenomena yang tidak hanya berkembang hanya pada komunitas tertentu. Namun eksistensinya sudah berkembang dalam bentuk yang bercorak transnasional. Hal itu dikarenakan hampir di seluruh negara terdapat fenomena radikalisme agama ini. Bahkan radikalisme agama juga bercorak transreligius karena dialami oleh semua agama yang berkembang di dunia ini. Di mana dapat dikatakan fenomena ini telah berkembang dan berlangsung lama. Sehingga kajian tentang radikalisme menjadi sebuah kajian menarik untuk diperhatikan.

Tumbuh suburnya radikalisme yang mengatasnamakan agama tidak lepas dari faktor-faktor yang melatarbelakanginya. Salah satu faktor yang ikut menjadikan subur pemahaman dan aksi radikalisme agama di Indonesia adalah pendidikan. Melalui pendidikan inilah yang membentuk karakter dan mampu mendorong seseorang melakukan segala tindakan. Sehingga lembaga pendidikan apa pun jenisnya memiliki tugas yang besar untuk menghadapi masalah ini. Terlebih lembaga pendidikan keagamaan.

Dalam konteks Indonesia, diskursus radikalisme agama-agama Islamdikaitkan dengan lembaga pendidikan tradisional, yakni pesantren. Bahkan pesantren ini merupakan salah satu bentuk pendidikan keagamaan di Indonesia yang mendapatkan perhatian secara khusus, lebih-lebih setelah terjadinya beberapa tindakan radikal yang mengatasnamakan agama. Sebenarnya dikaitkannya Islam radikal dengan pesantren ini merupakan sesuatu yang ambigu. Sebab lahirnya pesantren di Indonesia sebagai lembaga pendidikan keagamaan sebenarnya tidak didirikan untuk melahirkan radikalisme. Melainkan pesantren bertugas untuk mencetak kader-kader ulama yang berpengetahuan luas tentang agama (tafaqquh fi 'l-dīn). ${ }^{1}$ Hal ini karena di dalam pesantren

\footnotetext{
${ }^{1}$ Abdurrahman Wahid, "Pondok Pesantren Masa Depan", dalam Marzuki Wahid, dkk. (ed.), Pesantren Masa Depan, (Bandung: Pustaka Hidayah, 1999), h. 16.
} 
mengajarkan semua ilmu pengetahuan tentang agama, baik pengetahuan tentang hukum Islam, teologi, maupun tata cara berperilaku dan bersikap dengan sesama manusia.

Pesantren yang sejak awal perkembangannya merupakan institusi yang moderat dan akomodatif juga memiliki cara pandang dan pemikiran tersendiri tentang radikalisme. Sebagai lembaga pendidikan yang berbasis keislaman yang khas Indonesia pesantren telah menegaskan arti penting dalam menyebarkan budaya damai. Konsep tasāmuḥ, tawassuț, tawāzun, dan i'tidāl yang melekat pada komunitas pesantren merupakan bukti nyata, bahwa pesantren merupakan institusi yang menyemaikan nilai-nilai perdamaian dan anti terhadap radikalisme. Tulisan ini merupakan hasil penelitian yang secara khusus mengelaborasi diskursus radikalisme dan kontra radikalisme di Pesantren Soko Tunggal Semarang.

\section{B. Radikalisme dan Deradikalisasi}

\section{Radikalisme}

Radikalisme berasal dari akar kata radix (Latin) yang berarti akar. Dalam pengertian yang lain radikal sering juga dimaknai fundamental. Jika menyebut radikalisme dalam agama maka identik dengan fundamentalisme agama. Pengertian lain yang identik dengan kata radikalisme adalah fanatisme, ekstremisme, militanisme, dan lain-lain. Kata radikal juga sepadan dengan kata liberal, reaksioner, progresif dan lain-lain.

Kata radikal dengan demikian tidak sepenuhnya memiliki makna negatif, tetapi juga bisa positif. Sebagai contoh, jika dalam kajian filsafat, radikal bermakna mendalam. Berpikir radikal berarti berpikir secara mendalam dan seakar-akarnya. Namun demikian, kata radikal juga bisa bermakna negatif, misalnya radikalisme agama, sering dikonotasikan sebagai kelompok ekstremis dalam agama tertentu, atau bahkan bisa dimaknai kelompok teroris. Dengan kata lain, berbicara tentang kata radikal sangat bergantung pada konteks kalimatnya.

Qardhawi mengemukakan bahwa radikal dalam bahasa Arab identik dengan tațarruf yang berarti berlebihan. Kata tațarruf berlaku pemikiran dan perilaku. Oleh karananya makna dari tațarruf fi 'l-din adalah berlebihan dalam perilaku keberagamaan. Tentu saja, dalam konteks ini, kata radikal berkonotasi 
negatif. Lawan dari kata radikal dalam agama adalah moderat. Dengan kata lain, berpikir radikal dalam beragama berlawanan dengan berpikir moderat. ${ }^{2}$

Sejalan dengan pengertian ini, Mudjahirin Tohir mengemukakan bahwa istilah radikalisme sepadan dengan fundamentalisme, militanisme, dan ekstremisme. Radikalisme dalam konteks politik dan sosial keagamaan berarti sikap dan paham keagamaan yang yang melampaui batas kenormalan. ${ }^{3}$ Dengan demikian, makna radikalisme dalam agama sangat identik dengan fundamentalisme agama, fanatisme agama dan militanisme agama.

Meskipun radikalisme agama berkonotasi negatif, namun dalam konteks tertentu bisa saja bermakna positif. Pada dasarnya, semua pemeluk agama harus militan dan mengamalkan ajaran agamanya secara fundamental. Artinya dalam keyakinan dan amalan agama tidak boleh tawar-menawar dan tidak boleh kompromi dengan agama lain. Al-Qur'an mengajarkan bahwa bagimu agamamu dan bagiku agamaku. ${ }^{4}$ Dalam mengamalkan ajaran agama harus secara fundamental, yakni mengamalkan agama secara menyeluruh dan utuh ( $k a ̈ f f a h)$, serta tidak boleh mengamalkan agama sebatas kulit atau parsial.

Di pihak lain, Esposito lebih melihat istilah fundamentalisme Islam sebagai bentuk pemurnian terhadap ajaran Islam..$^{5}$ Kelompok fundamentalis Islam yang berupaya memurnikan ajaran Islam dengan kembali kepada sumber ajaran al-Qur'an dan Hadits Nabi Muhammad SAW. Kaum fundamentalis biasanya cenderung memahami ajaran Islam secara tekstual, dengan slogan "Kembali kepada al-Qur'an dan Hadits."

Dengan demikian, yang dimaksud fundamentalis Islam bukan mereka yang fanatisme berlebihan, ekstremis, atau kelompok teroris. Meski demikian, tidak dapat dipungkiri bahwa kelompok ekstrem dalam Islam pada umumnya adalah mereka yang berpaham fundamentalis. Kelompok radikal Islam di berbagai negara berupaya memerangi paham keislaman yang berbeda dengan mereka.

\footnotetext{
2Yusuf Qardhawi, Islam Radikal: Analisis terhadap Radikalisme dalam Berislam dan Upaya Pemecahannya, terj. Hawin Murthado, (Solo: Intermedia, 2004) h. 23.

${ }^{3}$ Mudjahirin Thohir, "Deradikalisme Keagamaan dalam Perspektif Sosial-Budaya" dalam seminar Nasional, "Deradikalisme Agama Melalui Peran Mubaligh di Jawa Tengah", Fakultas Dakwah IAIN Walisongo, 20 Juli 2011, h. 1.

${ }^{4}$ QS. al-Kafirun [109]: 6.

${ }^{5}$ John Esposito, Islam and State, (New york: Syracuse University Press, 1987) h. ix.
} 
Pada dasarnya gerakan fundamentalis radikal bukan hanya berbasis pada pemeluk agama Islam, namun juga menjadi fenomena yang terjadi di hampir semua agama di dunia. Bahkan menurut Jurgensmayer, fenomena kekerasan dan sikap revolusioner inheren dalam paham keagamaan. ${ }^{6}$ Meskipun anggapan ini bisa disebut terlalu berlebihan, namun bisa dipahami, karena ideologi agama sangat potensial menjadikan penganutnya berpaham radikal dan fanatis. Fanatisme dalam beragama bisa mendorong seseorang melakukan apa saja atas nama agama yang dianut. Bahkan para tokoh fudamentalisme radikal seringkali menggunakan dalil agama sebagai penguat doktrin mereka.

Di pihak lain, Tibi mengemukakan bahwa fundamentalisme bukan ekspresi keberagamaan tetapi pandangan sosial politik yang mendeklarasikan tatanan baru dalam segala hal, baik agama, sosial, budaya, hukum maupun politik. Gerakan fundamentalis Islam berupaya melawan segala sesuatu yang berbau Barat dan sekuler serta berupaya mengembalikan pada ajaran Islam yang murni. ${ }^{7}$

Gerakan Islam radikal menyuarakan pemahaman dan pengamalan Islam yang käffah. Pemahaman ini meniscayakan keharusan umat Islam menggunakan syariat Islam dalam segala hal. Al-Qur'an dan sunnah sebagai sumber ajaran Islam harus menjadi dasar dalam segala aspek kehidupan umat Islam. Umat Islam tidak boleh menjadikan syariat sebagai pedoman hanya dalam hal ibadah, namun syariat Islam harus juga menjadi tuntunan dalam kehidupan sosial, budaya dan politik. Umat Islam tidak boleh menggunakan dasar hukum lain selain al-Quran dan sunah Nabi Muhammad SAW. Umat Islam tidak boleh mempraktekkan tradisi atau budaya di luar yang diajarkan oleh syariat Islam. Oleh karenanya, gerakan Islam radikal melawan segala tindakan yang oleh mereka dianggap khurafat, tahayul dan bid'ah. Di antara ekspresi radikal yang mereka lakukan adalah dengan melakukan pengrusakan terhadap makammakan atau situs-situs keagamaan atau budaya yang mereka anggap sebagai sarang khurafat, seperti makam sahabat, makam wali, dan tempat-tempat suci lain yang biasa diziarai oleh umat Islam. Bahkan makam Nabi sekalipun juga berupaya mereka musnahkan untuk menghindari pengkultusan yang dilakukan oleh umat Islam.

\footnotetext{
${ }^{6}$ Mark Jurgensmayer, Teror Atas Nama Tuhan, terj. Sadat Ismail, (Jakarta: Nizam Press, 2002), h. xvi.

7Bassam Tibi, Ancaman Fundamentalisme: Rajutan Islam Politik dan Kekacauan Dunia Baru, (Yogyakarta:Tiara Wacana, 2000) h. 22-23.
} 
Syamsul Bahri sebagaimana dikutip oleh Gunaryo mengemukakan bahwa faktor-faktor yang mendorong munculnya radikalisme atau kekerasan dalam agama antara lain adalah: (1) Pergolakan sosial dan politik yang melanda dunia Islam; (2) emosi keagamaan dan fanatisme yang melahirkan sentimen keagamaan dan solidaritas sesama kelompok agama; (3) ideologi anti Westernisasi. Westernisasi dianggap telah menggerogoti pengamalan syariat Islam; (4) Faktor budaya akibat pengaruh kebudayaan atau tradisi lokal dan sekularisasi yang dibawa oleh Barat; (5) Ketidakmampuan pemerintahan Islam menyelesaikan masalah sosial, politik dan ekonomi yang dihadapi masyarakat; dan (6) propaganda media masa Barat yang cenderung memojokkan Islam. ${ }^{8}$

\section{Deradikalisasi}

Deradikalisasi atau de-radicalization adalah sebuah istilah sering digunakan untuk menggambarkan proses perubahan atau merubah pandangan orang atau masyarakat terhadap dunia, dari yang cenderung "ekstrem" menuju masyarakat yang normal. Konsep deradikalisasi menjadi sangat penting setelah melihat kasus terorisme yang terjadi berulang kali meskipun para pelaku telah ditindak dengan sangat tegas dan keras. Menghukum dan menindak secara tegas pelaku terorisme atau radikalisme tidak serta dapat menghentikannya. Bahkan sebaliknya, para pelaku terorisme justru mampu merekut pengikut baru, termasuk ketika mereka berada di dalam penjara.

Mengutip hasil kajian yang dilakukan oleh Septiani, bahwa sebuah laporan dari International Crisis Group (ICG) pada tahun 2007 menyebutkan kasus menarik yang terjadi di Lembaga Pemasyarakatan Kerobokan Bali. Para pelaku utama Bom Bali yaitu Amrozi, Imam Samudra dan Mukhlash bisa mempengaruhi narapidana lain dan para sipir. Salah seorang narapidana pelaku kriminal umum yang beragama Hindu, akhirya justru terpengaruh oleh "Trio Pelaku Bom Bali" tersebut pada saat di dalam penjara. Laporan tersebut juga menjelaskan bahwa bahwa Aman Abdurrahman, salah seorang teroris garis keras telah berhasil merekrut setidaknya 3 orang napi yang sebelumnya tidak memiliki kecenderungan untuk berjihad di penjara Sukamiskin, Bandung. ${ }^{9}$

\footnotetext{
${ }^{8}$ Ahmad Gunaryo, dkk, "Radikalisme Islam dan Upaya Deradikalisasi Paham Radikal," Laporan Penelitian, IAIN Walisongo, 2011, h. 40-46.

${ }^{9}$ Lihat dalam Septiani, "Pelaksanaan Deradikalisasi Narapidana Terorisme di Lembaga Pemasyarakatan Kelas I Cipinang", Jurnal Kriminologi Indonesia, Vol. 7 No. 1, Mei 2010, h. 108-133.
} 
Oleh karena itulah, deradikalisasi lebih banyak dijadikan sebagai alternatif yang lebih humanis dalam mengatasi masalah gerakan terorisme.

Deradikalisasi juga didefinisikan sebagai usaha untuk mengajak para pelaku teror (teroris) serta para pendukungnya untuk meninggalkan pendekatan kekerasan, seperti usaha diplomasi publik yang bertujuan untuk "memenangkan hati dan pikiran". ${ }^{10}$ Sementara menurut The International Centre for the Study of Radicalisation and Political Violence (ICSR) mendeskripsikan dengan istilah deradicalization dan disengagement, yaitu proses individu atau kelompok untuk melepaskan keterlibatan mereka dalam organisasi kekerasan atau kelompok teroris. ${ }^{11}$ Deradikalisasi secara substantif bertujuan untuk merubah tindakan dan ideologi individu atau kelompok. Sedangkan disengagement berkonsentrasi pada memfasilitasi perubahan perilaku, melepaskan ikatan (disengage) dan menolak penggunaan kekerasan.

Sebagai sebuah konsep tindakan, pendekatan dan strategi aksi deradikalisasi harus dikaitkan dengan akar katanya itu sendiri, radikal atau radikalisme. Radikal artinya dasar atau akar. Sikap dan pandangan radikal bila hanya berada para ranah keilmuan, hal itu justru dinilai positif, karena merupakan ciri berpikir filsafati. Dengan cara berpikir filsafati itulah akan mampu menyelam sampai lapis-lapis makna, bukan hanya lapis permukaan. Karena yang menjadi persoalan adalah bila sikap radikal tersebut pada ranah gerakan sosial keagamaan, maka sikap radikal itu disetarakan dengan gerakan fundamentalisme, militanisme dan ektremisme, yaitu tindakan yang dipandang melampaui batas kenormalan dalam beragama, sehingga dampaknya justru merugikan tatanan kehidupan masyarakat yang plural. ${ }^{12}$

Dalam konteks Islam, gerakan radikalisme atau fundamentalisme agama diidentifikasi sebagai gerakan yang memiliki ciri umum: (a) gerakan-gerakan Islam yang secara politik menjadikan Islam sebagai ideologi dan secara budaya menjadikan Barat sebagai the others; (b) memiliki prinsip yang mengarah pada paham perlawanan atau oppotionalisme; (c) penolakan terhadap hermeneutika

\footnotetext{
${ }^{10}$ Dalam Septiani, “Pelaksanaan Deradikalisasi Narapidana Terorisme di Lembaga Pemasyarakatan Kelas I Cipinang", Jurnal Kriminologi Indonesia, Vol. 7 No. I, Mei 2010, h. 108-133.

${ }^{11}$ International Crisis Group (ICG), 2007: 1, sebagaimana dikutip oleh Septiani, dalam Septiani, "Pelaksanaan Deradikalisasi Narapidana Terorisme di Lembaga Pemasyarakatan Kelas I Cipinang", Jurnal Kriminologi Indonesia, Vol. 7 No. I, Mei 2010, h. 108-133.

${ }^{12}$ Mudjahirin Thohir, Multi-Kulturalisme, Agama, Budaya dan Sastra, (Semarang: Gigih Pustaka Mandiri, 2013),h. 25.
} 
karena pemahaman al-Qur'an semata hanya skriptualistik; (d) secara etimologis, dalam wilayah gerakan sosial politik revivalisme dan menolak pluralisme; (e) menolak perkembangan historis dan sosiologis, dan memandang bahwa segala aktivitas manusia di dunia harus menyesuaikan diri dengan teks alQur'an. ${ }^{13}$

Gerakan radikalisme atau fundamentalisme, juga dengan istilah gerakan revivalisme, yaitu sebuah gerakan yang ingin mengekspresikan keinginan umat Islam untuk kembali menjadikan Islam sebagai landasan hidup (way of life) sebagai alternatif dari sekularisme. ${ }^{14}$ Gerakan revivalisme ini memiliki prinsipprinsip sebagai berikut: (a) Islam adalah al-din wa daulah, agama dan negara. Islam dipandang sebagai sistem kehidupan yang total, bersifat universal dan dapat diterapkan pada semua keadaan dan waktu; (b) fondasi Islam adalah alQur'an dan Sunah Nabi serta tradisi para sahabat. Umat Islam diperintahkan untuk kembali kepada akar-akar Islam yang awal tersebut, serta praktek Nabi secara puritan; (c) puritanisme dan keadilan sosial; (d) kedaulatan dan hukum Allah berdasarkan Syariat. Tujuan umat Islam adalah menegakkan kedaulatan Tuhan di bumi dalam sebuah tatanan Islam (nizam islami); (e) jihad sebagai pilar menuju nizam islami tersebut. Tujuan dari jihad adalah menaklukkan semua halangan yang mungkin akan menghambat penyiaran Islam ke seluruh dunia, baik berupa negara, sistem sosial dan tradisi-tradisi asing. ${ }^{15}$

Gerakan revivalisme Islam sebagai fenomena Islam Timur Tengah masuk ke Indonesia melalui empat jalur transmisi, yaitu: (1) melalui para alumnus Timur Tengah; (2) melalui gerakan dakwah kampus dengan sistem usrah; (3) melalui penyebaran buku-buku dan sarana informasi lainnya; (4) melalui kontak personal dengan para aktivis gerakan revivalisme Islam di Timur Tengah. ${ }^{16}$ Transmisi melalui beberapa jalur tersebut menurut Imdadun Rahmat melahirkan pengaruh yang bertingkat-tingkat. Yang paling intensif yaitu pengaruh dalam bentuk diadopsinya pemikiran dan ideologi serta manhaj gerakan. Beberapa gerakan Islam revivalis di Indonesia yang merepresentasikan keterpengaruhannya antara lain pada kasus Gerakan Tarbiyah (PKS) yang mengadopsi

\footnotetext{
${ }^{13}$ Mudjahirin Thohir, Multi-Kulturalisme, Agama, Budaya dan Sastra, (Semarang: Gigih Pustaka Mandiri, 2013), h. 21.

${ }^{14}$ Imdadun Rahmat, Arus Baru Islam Radikal, Transmisi Islam Timur Tengah ke Indonesia, (Jakarta: Erlangga, 2005), h. 154.

15Imdadun Rahmat, Arus Baru Islam Radikal, Transmisi Islam Timur Tengah ke Indonesia, h. 155.

16Imdadun Rahmat, Arus Baru Islam Radikal, Transmisi Islam Timur Tengah ke Indonesia, h. 157.
} 
pemikiran dan ideologi serta manhaj Ikhwanul Muslimin di Mesir. Hizbut Tahrir Indonesia merepresentasikan jaringan Hizbut Tahrir Internasional yang berbasis di Yordania. Dakwah Salafi merepresentasikan jaringan Dakwah Salafi yang berada di Saudi Arabia, Kuwait dan Yaman..$^{17}$ Ketiga gerakan tersebut, menurut Imdadun Rahmat, merupakan aktor penting gerakan revivalisme Islam di Indonesia. Ketiganya memiliki ciri-ciri revivalis sebagaimana disebutkan di atas. ${ }^{18}$

Selain faktor-faktor kaitan dengan jaringan internasional dunia Islam, situasi tersebut juga bertemu dengan kondisi-kondisi umum sosial kemasyarakatan Indonesia yang berada dalam situasi transisi demokratis, faktor dinamika perekonomian, serta faktor-faktor lainnya. Dengan kata lain, Faktorfaktor yang mempengaruhi kemunculan radikalitas keagamaan bisa muncul dari internal dan eksternal serta dialektika keduanya. ${ }^{19}$

\section{Fenomena Pesantren Soko Tunggal}

Soko Tunggal merupakan salah satu pesantren di Kota Semarang. Pesantren ini pada berdiri pada tahun 1997 dengan nama pesantren AnNuriyyah, namun masyarakat lebih mengenal pesantren ini dengan nama Pesantren Soko Tunggal. Nama Soko Tunggal berasal dari bangunan masjid yang menjadi cikal bakal pesantren ini dengan soko tunggal (satu tiang). Masjid Soko Tunggal itu kini jauh lebih baik. Ditunjang dengan sarana prasarana memadai serta ada pengembangan bentuk dan model pendidikannya. Masjid Soko Tunggal yang amat sangat sederhana sekarang berdiri di atas lahan satu hektar di Jalan Sendang Guwo Raya No. 36-43 di Kota Semarang, yang kemudian dikenal sebagai Pondok Pesantren Soko Tunggal.

Pondok Pesantren Soko Tunggal sampai sekarang ini tidak menerapkan konsep klasikal dalam mendidik santri-santrinya. Artinya, tidak ada kurikulum baku dan terstruktur atau pengajian dengan bahasan-bahasan khusus. Kegiatan belajar mengajar tidak menggunakan kitab-kitab kuning tertentu yang disesuaikan mata pelajaran sebagaimana pesantren yang menggunakan sistem klasikal. Andai pun pengajaran yang menggunakan referensi itu hanya kitabkitab kecil seperti Fatḥ al-Qarīb, Tafsìr Jalālain, Ajurümiyyah dan Imriți (Naḥwu

\footnotetext{
17Imdadun Rahmat, Arus Baru Islam Radikal, Transmisi Islam Timur Tengah ke Indonesia, h. 157.

18Imdadun Rahmat, Arus Baru Islam Radikal, Transmisi Islam Timur Tengah ke Indonesia, h. 158.

${ }^{19}$ Mudjahirin Thohir, Multi-Kulturalisme, Agama, Budaya dan Sastra, h. 31.
} 
dan Șaraf), Fath al-Mu'în dan Sulam Tawfiq. Karena santri-santri yang menimba ilmu di Pondok Pesantren Soko Tunggal rata-rata sudah matang dari sisi keilmuan agama, selain itu juga telah banyak tahu dan bahkan ada yang sarjana dari perguruan tinggi Islam.

Oleh Gus Nuril dikatakan bahwa santri-santri yang matang ini sesungguhnya yang jadi kiai di Pondok Pesantren Soko Tunggal. Misalnya, Kiai Masnun Rosyid al-Hafizh dan Kiai Abdullah Adib. Adapun pengajian yang sifatnya rutin yaitu pada malam Rabu, malam Kamis dan malam Jum'at. Rutinan ngaji hanya berisi ritual riyādah dan shalat kemudian bahasan tasawuf. Sedangkan tiap-tiap bulan khataman al-Qur'an. Kegiatan harian sebagaimana biasa anak-anak mengaji. Ada pula yang tiap hari menghafal al-Qur'an. Ditambah dengan pembekalan keterampilan otomotif dan peternakan. Pada akhir tahun diselenggarakan kegiatan-kegitan selayaknya pesantren umumnya yaitu Akhirussanah.

Secara umum proses pengajaran di Pondok Pesantren An-Nuriyah bersifat kondisional. Tidak harus duduk di masjid atau tempat khusus lain di pesantren. Pada suatu kesempatan baik siang atau malam ketika orang datang silaturahmi di sana ada proses interaksi atau tanya jawab, maka pada saat itulah proses pengajaran berlangsung. Orang-orang yang datang dari kalangan biasa, perusahaan, instansi dan lain sebagainya juga disebut sebagai santri. Tidak ada materi khusus yang diajarkan. Pelajaran diberikan Gus Nuril sesuai kebutuhan santri baik dari kalangan Muslim maupun non-Muslim. Untuk yang teakhir itu Gus Nuril tidak menyebutnya kafir atau non-Islam. Mereka sama beragama Islam hanya belum sempurna. Tugas Gus Nuril menyempunakannya sehingga bisa ber-Islam. Baru saja ada anaknya sampurna (non-Muslim) mengajak debat perihal tasawuf. Sekarang malah dia ingin menyempurnakan agamanya dengan umroh.

Pola belajar mengajar di Pondok Pesantren Soko Tunggal yang demikian ini oleh Gus Nuril dinamai sebagai 'pola sendiri'. Dalam sejarah Islam dikenal pernah ada seorang tokoh masyhur bernama Ibnu Abbas yang membuat pesantren dengan 'pola sendiri'. Ibnu Abbas dalam mendidik santri-santrinya tidak menggunakan sistem klasikal. Sebagaimana yang dilakukan Gus Nuril sekarang hanya memberikan materi yang dibutuhkan para santri. Apalagi para santri sudah sarjana dan pernah mengenyam pendidikan yang tersistem. Maka, pelajaran yang pokok di Pondok Pesantren Soko Tunggal yaitu pengenalan agama untuk aplikasi dan pembekalan moral semata. Mengajarkan supaya ruh 
Islam bisa dipakai untuk bekal hidup sehari-hari. Tidak ada ijazah yang dikeluarkan bagi lulusan pesantren An-Nuriyah. Adapun yang dimaksud lulus itu misalnya sudah hafal al-Qur'an, menikah, ke luar atau berumah tangga sendiri.

Pesantren yang menerapkan 'pola sendiri' ini juga tidak punya catatan resmi berapa banyak santrinya. Jumlah santri biasanya diukur dari jumlah pembagian sarung di Bulan Ramadhan. Perlu diketahui bahwa tiap-tiap jelang Lebaran (Idul Fitri) Pondok Pesantren Soko Tunggal membagikan sarung gratis sebanyak 1.500 untuk santrinya. Sarung sejumlah itu pun tidak mencukupi keperluan semua santri An-Nuriyah. Para santri dari daerah-daerah rela berdatangan ke Soko Tunggal hanya sekadar mengambil sarung. Padahal, jika dinilai nominal, ongkos pulang pergi untuk ambil sarung jauh lebih mahal daripada harga sarung itu sendiri. Tetapi, kalau tidak mengambil sarung dari gurunya serasa kurang afdal. Itulah cara pesantren 'Bhinneka Tunggal Ika Multiagama' ini menghitung jumlah santrinya.

\section{Diskursus Radikalisme di Pesantren}

\section{Akar Radikalisme}

Radikalisme dalam agama bagi kalangan pesantren bukanlah sesuatu yang baru dan asing. Literatur pesantren telah mencatat dengan jelas bahwa sejak Nabi Adam as., keyakinan agama dalam perkembangannya telah dicederai oleh pemahaman radikal para pengikutnya. Hal ini dapat dilihat dalam sejarah nabinabi terdahulu, seperti kisah Nabi Idris, Nabi Zakaria, Nabi Yahya, Nabi Musa dan Nabi Isa.

Bagi komunitas Muslim, sebagaimana dikemukakaan Gus Nuril,20 fundamentalisme dalam beragama adalah penting, bahkan dianjurkan dan menjadi keharusan. Dalam menjalankan agama, umat Islam harus melakukan syariat atau ajaran agama secara käffah. Käffah bisa dipahami sebagai pemahaman yang fundamental dalam beragama. Beragama atau menjalankan syariat agama tidak hanya sebagian-sebagian, atau hanya kulit luar, tapi harus mendalam dan seakar-akarnya. Fundamentalisme dalam pengertian ini, menurut ulama pesantren adalah pemahaman agama yang benar.

20Wawancara dengan Gus Nuril, Pengasuh Pesantren Soko Tunggal, 15 November 2014.

Walisongo, Volume 23, Nomor 1, Mei 2015 
Apa yang dikemukakan Gus Nuril menunjukkan bahwa radikalisme yang terjadi adalah akibat kesalahan dalam memahami makna fundamental dalam agama. Kelompok radikal mendasarkan sikap radikal yang dilakukannya berdasarkan perintah Allah untuk menjalankan agama secara kâffah. Untuk itu maka dalam menjalankan agama tidak boleh toleran dengan beragam keyakinan atau kepercayaan agama lain. Menurut Hassan Hanafi gerakan Islam radikal bisa jadi merupakan respons terhadap Islam ritualistik. Kaum radikalis menyuarakan slogan Islām käffah yang hendak menegaskan bahwa Islam memiliki sistem yang lengkap, baik dalam bidang ibadah maupun politik. ${ }^{21}$

Berkembangnya gerakan Islam radikal di Indonesia menurut Gus Nuril juga tidak luput dari kondisi masyarakat Indonesia yang miskin. Sementara, kelompok-kelompok radikal membawa misi dakwah dengan sponsor dari Wahabi Arab Saudi yang memiliki dana besar. Keberhasilan kelompok ini dalam meraih jabatan-jabatan publik juga tidak luput merupakan faktor yang mempengaruhi pesatnya perkembangan kelompok radikal Islam di Indonesia. Gerakan zakat, infak dan sedekah yang dimotori oleh kelompok Islam radikal cukup efektif dalam mengumpulkan dana umat Islam Indonesia. Mereka melakukan gerakan ini secara professional, sehingga menarik minat para aghniy $\bar{a}^{\prime}$ (orang-orang kaya) untuk menyumbangkan hartanya.

Hal ini sejalan dengan pernyataan Hassan Hanafi bahwa radikalisme Islam terjadi akibat keterbelakangan kaum Muslimin yang diakibatkan karena umat Islam kehilangan identitas. Untuk itu, maka sebagai solusinya adalah dengan kembali kepada ajaran-ajaran Islam yang murni (al-așlaḥ).22

Alasan lain yang menjadi pemicu munculnya paham radikal adalah kekuasaan. Mereka menentang Negara yang tidak menggunakan syariat Islam sebagai hukum negara. Semula dipicu dengan tingkah laku penguasa yang tidak sesuai dengan apa yang mereka harapkan. Kondisi ini dimanfaatkan oleh Amerika dan Yahudi untuk memecah belah umat Islam. Kepentingan ekonomi Negara adidaya juga ikut andil menjadi motif politik pemecah belah ini.

Dalam pandangan Gus Nuril, gerakan Islam radikal adalah alat yang digunakan oleh Barat dan Amerika untuk memecah belah umat Islam. Untuk itu

\footnotetext{
${ }^{21}$ Hasan Hanafi, Islam in the Modern World; Tradition, Revolution and Culture, Vol. II, (Cairo: Dar Kebaa Bookshop, 2000), h. 15-17.

${ }^{22}$ Hasan Hanafi, al-Dīn wa al-Ṭaurah; Ușūliyyah al-Islāmiyyah, (tt.p.: Maktabah Madbouli, t.th.), h. 4-8.
} 
umat Islam harus waspada terhadap hal ini. Tujuan kelompok ini bukan hanya menguasai Negara, tetapi juga menghancurkan negara dengan segala kepentingannya. ${ }^{23}$ Menurut pandangan Gus Nuril, gerakan Islam radikal menganggap kebenaran hanya menjadi milik mereka. Mereka beranggapan bahwa Islam merekalah yang kāffah. Sementara Islam yang lain dianggap bid'ah, syirik dan khurafat. Menurut mereka Islam käffah tidak mengenal pembaharuan, karena pembaharuan adalah bentuk bid'ah.

Hal ini, menurut gus Nuril sangat berbeda dengan Islam pesantren yang bermazhab. Meskipun banyak mazhab yang dianut umat Islam namun antara satu dan yang lain saling menghormati. Sikap saling menghormati ini dicontohkan oleh para imam mazhab terhadap imam yang lain. Meskipun mereka berbeda pendapat namun saling menghormati. Demikian pula dengan perbedaan pendapat di kalangan santri dan ulama pesantren. Meskipun mereka berbeda pendapat dalam bahth al-masāill (forum diskusi), namun mereka tetap menghargai pendapat ulama lain.

\section{Ideologi Islam Radikal}

Kalangan pesantren pada umumnya memiliki pemahaman bahwa gerakan Islam radikal yang ada di dunia, khususnya di Indonesia, berawal dari gerakan pemurnian yang dilakukan oleh Muhammad bin Abdul Wahab atau yang dikenal dengan Wahabi. Karena gerakan inilah yang sejak berdirinya telah melakukan beragam tindakan kekerasan dengan beragam bentuk, baik dengan melakukan pembunuhan terhadap ulama yang berseberangan maupun penghancuran terhadap situs-situs bersejarah di Mekah dan sekitarnya. Kelompok Wahabi yang semula tidak terlalu besar dan kuat di Arab Saudi kemudian menjadi pemenang karena berhasil mempengaruhi penguasa yang berkonspirasi dengan Inggris dan Perancis.

Islam yang ada di Indonesia dibawa oleh Walisongo. Mereka adalah ulama sufi yang menyebarkan Islam ke Indonesia, saat Indonesia masih ada di bawah kekuasaan kerajaan Hindu-Buddha. Masyarakat Indonesia saat itu pada umumnya beragama Hindu, Buddha, pengikut animisme dan dinamisme. Kehadiran Walisongo menjadikan Nusantara berubah menjadi Muslim. Hal itu tidak lain

23Wawancara dengan Gus Nuril, Pengasuh Pesantren Soko Tunggal, 15 November 2014.

Walisongo, Volume 23, Nomor 1, Mei 2015 
karena sikap moderat para wali yang sedemikian arif menyikapi ragam budaya masyarakat yang telah mapan. Walisongo tidak dengan serta merta menghapuskan tradisi lama dan menghancurkan situs-situs sejarah kerajaan HinduBuddha, namun menjaganya tetap lestari dan mengisi tradisi budaya lama dengan nilai-nilai syariat Islam.

Walisongo adalah figur-figur sufi yang arif dan bijaksana dalam menjalankan dakwahnya. Cara mereka sangat berbeda dengan cara orang Wahabi yang mendakwahkan Islam sengan kebencian dan penghancuran. Orang-orang Wahabi bukan hanya menjadikan kelompok non-Muslim sebagai musuhnya, bahkan umat Islam yang memiliki pemahaman keislaman berbeda pun dijadikan sebagai musuh dan dibantai. Menurut keterangan Gus Nuril, Walisongo pada umumnya berasal dari Samarqand (Uzbekistan) dan Gujarat. Pada umumnya mereka bermazhab Hanafi dan Hanbali.

Sampai saat ini, kelompok-kelompok radikal Islam yang berkembang di segala penjuru dunia menurut Gus Nuril adalah berpaham Wahabi. Di Irak dan Suriah saat ini muncul ISIS (Islamic State of Iraq and Syiria). Pada mulanya, kelompok ini disponsori oleh Arab Saudi dan Amerika. Meski demikian, karena gerakan kelompok ini cenderung berlebihan akhirnya Arab Saudi dan Amerika pun berupaya memerangi mereka.

\section{Karakter Islam Radikal}

Kalangan pesantren, sebagaimana pandangan Gus Nuril memandang bahwa di antara ciri komunitas Islam radikal adalah suka mengkafirkan kelompok lain. Orang-orang yang tidak sepaham dengan mereka dianggap telah keluar dari pemahaman Islam yang benar. Ungkapan Gus Nuril tersebut menunjukkan bahwa kalangan pesantren paham betul, terjadinya radikalisme agama dan sejarahnya, bukan hanya dalam konteks Islam tetapi agama-agama sebelum Islam pun mereka pahami. Wajar jika pesantren memiliki kekuatan pemahaman yang utuh terkait munculnya radikalisme dalam pemahaman agama. Untuk itu yang dilakukan oleh pesantren dalam menghadapi paham radikalisme agama, tidak dengan kekerasan yang sama, namun dengan segala upaya persuasif untuk memahamkan masyarakat Islam terhadap bahaya radikalisme agama.

Di masa kekuasan dinasti atau kekhalifahan Islam, kekerasan juga banyak terjadi. Sejak saat ditinggal oleh Rasulullah hingga masa kemunduran Islam di 
akhir kekhalifahan Turki Utsmani, peperangan dan penindasan atas nama agama dalam kekuasaan Islam juga terjadi, baik akibat pemahaman yang salah maupun oleh kepentingan kekuasaan. Di masa kekuasaaan Utsman bin Affan dan Ali bin Abi Thalib, peperangan antar umat Islam terjadi. Mereka berperang untuk mempertahankan kebenaran masing-masing. Masing-masing kelompok memiliki tafsirnya tersendiri terhadap teks-teks suci yang mereka pedomani. Pemahaman kitab suci tersebut berbaur dengan kepentingan kekuasaan dan golongan yang berakibat pertentangan hingga pertumpahan darah.

Menurut keterangan Gus Nuril, Islam radikal menghalalkan segala cara untuk mencapai tujuan. Mereka menafsirkan teks sesuai dengan hawa nafsu mereka. Sehingga layak, jika gerakan mereka di Indonesia sulit diterima. Pelaku pola ini hanya pengikut-pengikut setia mereka dan pemimpin mereka saja. Mereka adalah kader Islam radikal yang didik secara langsung oleh para tokoh Islam radikal di luar negeri, seperti di Mekah, Madinah, Yaman dan lain-lain. Saat mereka memimpin partai di Indonesia pun melakukan menghalalkan segala cara, termasuk yang jelas-jelas haram. Namun mereka berdalih untuk perjuangan fi sabīlillāh yang haram pun menjadi halal..24

Pola gerakan ini sesungguhnya tidak jauh dengan gerakan-gerakan radikal Islam di Indonesia. Mereka pada umumnya menganggap sesat orang-orang yang suka ziarah kubur dan menziarahi makam para wali. Demikian pula dengan kegiatan keagamaan yang dilaksanakan dengan menjadikan budaya dan tradisi sebagai wadahnya juga dianggap bid'ah. Isu pembongkaran makam Nabi Muhammad SAW. dan para wali sebenarnya bukan hal baru. Jika tidak ada intervensi dari luar negeri seperti ulama-ulama Indonesia, bisa jadi saat ini makam Nabi Muhammad SAW. sudah tidak ada lagi. ${ }^{25}$

Islam Indonesia adalah Islam moderat dan mengakar dengan budaya Sunni moderatnya, sehingga sulit ditembus oleh kelompok-kelompok radikal Islam. Apalagi dengan adanya pesantren yang merupakan benteng pertahanan Islam moderat dan NKRI. Masyarakat Indonesia tidak mudah menerima pahampaham baru yang radikal, karena mereka telah memiliki model yang sulit digantikan, yakni ulama-ulama pesantren. Ideologi moderat ulama pesantren

\footnotetext{
${ }^{24}$ Wawancara dengan Gus Nuril, Pengasuh Pesantren Soko Tunggal, 15 November 2014.

25Abdurrahman Mas'ud, Intelektual Pesantren: Perhelatan Agama dan Tradisi, (Yogyakarta: LKiS, 2004), h. 258.
} 
sangat dekat dan selaras dengan ideologi masayarakat asli Jawa pada khususnya dan Nusantara pada umumnya.

Di Indonesia, pesantren tetap merupakan prototipe masyarakat ideal bagi penduduk Indonesia. Bagi orang Indonesia, kiai (ulama) pesantren merupakan pewaris para nabi yang tidak bisa digantingan dengan yang lain, khususnya dalam pemahaman keagamaan. Meskipun dalam bidang politik kiai tidak lagi menjadi figur panutan yang utama, namun dalam paham keagamaan masyarakat Indonesia tatap menjadikan kiai sebagai figur sentral.

Islam radikal sangat menentang keragaman atau pluralisme, sementara pesantren telah terbiasa dengan keragaman. Bagi Gus Nuril, keragaman atau pluralisme adalah kehendak Allah. Menurut Gus Nuril sebenarnya tidak masalah dengan fundamentalisme dan paham radikal yang mereka yakini. Yang terpenting adalah tidak dengan menganggap sesat dan memusuhi serta bertindak kekerasan dengan kelompok lain yang berbeda. Ketika sekelompok orang bertindak keras terhadap orang yang berbeda pendapat dapat disebut pemaksaan. Pendapat orang bersifat relatif, maka tidak boleh ada seorang pun yang memaksakan pendapatnya pada orang lain. Menafsirkan boleh-boleh saja, ber-ijtihād juga boleh, tetapi tidak memaksakan hasil penafsiran dan ijtihad-nya untuk orang lain, apalagi dengan kekerasan.

\section{Pesantren versus Radikalisme}

Pada umumnya, pesantren di Indonesia merepresentasikan lembaga pendidikan yang berhaluan moderat Sunni, Ahl al-Sunnah wa 'l-Jamā'ah. Komunitas ini menjadikan al-Qur'an dan al-Sunnah sebagai sumber ajaran Islam di samping ijmā' (kesepakan ulama) dan qiyās (analog). Sebagai komunitas Sunni moderat, pesantren memiliki ciri khas yang tidak dimiliki oleh komunitas lain di luar pesantren. Ciri utama pesantren adalah adanya kiai yang menjadi panutan, madrasah sebagai tempat belajar, masjid sebagai tempat ibadah, santri yang belajar dan pondok sebagai tempat tinggal santri. Kondisi ini menjadikan pesantren sebagai tempat yang sangat kondusif dalam proses pendidikan dan pengajaran, pelatihan sikap dan pembinaan ketrampilan.

Karena ideologi yang dianut pesantren di Indonesia pada umumnya cenderung moderat, maka pesantren jauh dari segala bentuk ekstremitas, baik ekstrem kiri maupun kanan. Ideologi Sunni yang dianut umumnya pesantren di 
Indonesia ada di antara ekstremitas penggunaan logika dan rasionalitas Mu'tazilah dan ekstremitas tekstual yang radikal seperti paham Khawarij.

Masyarakat Sunni yang ada di pesantren masih menempatkan naș alQur'an dan al-Sunnah sebagai sandaran utama dan logika sebagai pendukungnya, berbeda dengan kaum Mu'tazilah yang lebih mengedepankan logika dan rasionalitas dibanding wahyu. Masyarakat pesantren lebih bersikap moderat dalam memandang sesuatu, tidak seperti kaum khawarij yang senderung ekstrem dalam melihat kelompok yang berbeda, bahkan sampai menumpahkan darah dalam rangka meraih tujuan dan membela ideologinya.

Sebagaimana komunitas Sunni, pada umumnya pesantren di Indonesia bebas dari fundamentalisme dan terorisme. Bahkan tidak jarang pesantren justru secara khusus berdiri untuk membentengi umat Islam Indonesia dari paham radikal atau fundamentalis yang cenderung melakukan kekerasan atau teror.

Pesantren melalui para kiai dan santrinya menawarkan model Islam moderat yang lebih raḥmatan li 'l-'älamin (ramah terhadap alam). Lebih terbuka dan menghargai beragam pandangan dan penafsiran yang muncul dan berkembang di antara umat Islam. Pesantren bukan saja menghargai dan menghormati sesama Muslim tetapi juga dengan umat lain. Pesantren lebih mengedepankan kesatuan dan persatuan dalam perbedaan, serta menjaga keutuhan NKRI. Untuk itulah maka ulama-ulama pesantren memandang Pancasila dan UUD 45 sebagai ideologi final dari NKRI. Bagi komunitas pesantren, paham radikal, khususnya yang dimotori oleh kelompok Wahabi merupakan paham dari luar Indonesia yang berupaya merongrong Pancasila dan keutuhan NKRI. Untuk itu, paham radikal harus diwaspadai. Umat Islam Indonesia harus dijaga dari pengaruh kelompok radikal yang membahayakan kelangsungan NKRI.

Kondisi ini sejalan dengan pandangan Abdurrahman Mas'ud yang menyatakan bahwa masyarakat moderat Sunni yang di dalamnya komunitas pesantren memiliki karakter antara lain: (1) Tidak melawan penguasa atau pemerintah yang ada, kecuali jika penguasa tersebut melakukan kedhaliman dan kesewenang-wenangan, maka harus diberikan peringatan. (2) Tegas dan kaku dalam menjaga kesatuan dan persatuan, melawan upaya disintegrasi dan kekerasan. (3) Bersikap moderat ala Ahl al-Sunnah wa '-Jamā'ah. Menempat- 
kan diri diantara dua kutub ekstrem kiri dan ekstrem kanan; antara khawarij dan Syi'ah. (4) Bersikap normatif dan menegakkan prinsip kebebasan spiritual dan menetapkan standar syari'ah. ${ }^{26}$ Atas dasar karakter itulah maka komunitas pesantren menolak segala bentuk paham yang ekstrem atau radikal.

\section{E. Pola Resistensi Soko Tunggal terhadap Gerakan Radikalisme}

\section{Soko Tunggal: Meneguhkan Islam Moderat}

Mengamati profil Pesantren Soko Tunggal cukup menarik. Dari segi namanya saja, kita dapat merasakan kuatnya muatan kearifan lokal. Pada umumnya pesantren banyak menggunakan nama-nama berbahasa Arab seperti "Raudhatut Thalibin" yang artinya "Taman para Pelajar", nama pesantren di Rembang Jawa Tengah asuhan KH. Mushtofa Bisri atau Gus Mus. Kemudian pesantren "AlAnwar" Sarang Rembang, asuhan Kiai Maemun Zubair, juga memakai bahasa Arab. Di Solo ada pesantren yang sangat kesohor karena dipimpin seorang Ustad Abu Bakar Ba'ashir, tokoh yang sangat dikenal radikal, yaitu pesantren "AlMukmin" Ngruki Surakarta. Sementara pesantren yang diasuh KH. Nuril Arifin, atau Gus Nuril, tetap dengan hanya memakai istilah Soko Tunggal, yang artinya satu tiang saja.

Pesantran Soko Tunggal adalah bagian dari ribuan pesantren tradisional di kalangan $\mathrm{NU}$, yang merupakan basis pengembangan Islam moderat, dan meneguhkan nilai-nilai yang dikembangkan oleh Walisongo, penyebar Islam di pulau Jawa. Lihat saja dengan statemen Gus Nuril tentang identitas pesantren kaitannya dengan budaya:

"Sudah dari sono-nya, yang namanya pesantren itu pusat kebudayaan. Maka Islam bisa berkembang tanpa peperangan di tanah Jawa itu, karena dia menguasai budaya. Kun khaira ummat ta'murūna bi'l-ma'rüf ini budaya kaitannya. Maka sampai Sunan Kalijaga membikin gamelan, membikin carangan wayang. Yang namanya Pandawa Moksa, Semar Mbangun Khayangan, itu kan karangan Sunan Kalijaga untuk memberikan nuansa kebatinan tasawuf Islam yang namanya tasawuf Islam lewat wayang"..."Sampai caranya bertasawuf para wali dulu itu dibikin nyanyian dolanan, 'Sluku-sluku bathok, bathok'e ela-elo, si rama menyang Solo, oleh-oleh payung kutha, PakJendit lololobah, wong mati ora obah, nek urip golek duit'. Itu kan sesungguhnya ajaran

\footnotetext{
${ }^{26}$ Abdurrahman Mas'ud, Intelektual Pesantren: Perhelatan Agama dan Tradisi, (Yogyakarta: LKiS, 2004), h. 258.
} 
tasawuf yang sangat luar biasa. Kayak Dandang Gula. Sluku-sluku badnaka, kumbahen nang Timur. La ila ha illallah, bathok'e ela-elo. Siru ma yak silu, untuk mencapai Allah harus mencapai menggunakan tawasul kepada Allah dalam bentuk amal, jembatan emas. Itu ajaran tasawuf dan budaya. Jadi kalau kaitannya dengan budaya, pesantren kok tidak mengenal budaya keblinger".27

Statemen Gus Nuril di atas menegaskan posisi pesantren Soko Tunggal merupakan kelanjutan (continuity) dari karakter pesantren yang dibangun oleh Walisongo, sebagai peletak batu pertama pesantren di Indonesia. Walisongo adalah tokoh-tokoh penyebar Islam di pulau Jawa yang berhasil menstransmisikan keilmuan Islam di Nusantara melalui dua jalur, jalur kultural dan jalur struktural. Jalur kultural dilakukan oleh Walisongo melalui dakwah Islam kepada masyarakat dengan menyelenggarakan pengajian di masjid-masjid dan mendirikan pesantren. Sedangkan jalur struktual dilakukan dengan mengislamkan penguasa atau ikut terlibat dalam pendirian kekuasaan baru, seperti Kesultanan Demak dan Cirebon. ${ }^{28}$

Transmisi keilmuan yang disebarkan oleh Walisongo, terutama di Jawa, bercorak akomodatif terhadap kebutuhan masyarakat setempat. Walisongo berusaha mengadaptasikan Islam ke dalam tradisi lokal masyarakat setempat, sehingga Islam lebih berwarna lokal. Adat-istiadat yang sudah lama dipraktikkan masyarakat seperti selamatan dan sebagainya, tidak dibabat habis. Sebaliknya malah diberikan kesempatan untuk berkembang, dengan disuntikkan warna keislaman, sehingga terjadi akulturasi antara Islam dan budaya lokal. ${ }^{29}$

Karakter inilah yang sampai sekarang masih manjadi corak keberagamaan masyarakat Indonesia, terutama di Jawa, yaitu keberagamaan yang moderat. Model keberagamaan seperti sangat berbeda dengan model keberagamaan yang puritan sebagaimana model yang dikembangkan oleh kalangan Islam radikal di Indonesia, yang sama sekali tidak mengakomodasi aspek-aspek lokal dalam keislaman. Wajah keislaman di tangan kalangan Islam radikal berubah menjadi berwajah serba Arab.

\footnotetext{
27Wawancara dengan Gus Nuril, Pengasuh Pesantren Soko Tunggal, 15 November 2014.

${ }^{28}$ Mastuki HS, dkk (ed.), Intelektualisme Pesantren, Potret Tokoh dan Cakrawala Pemikiran di Era Pertumbuhan Pesantren, (Jakarta: Diva Pustaka Jakarta, 2004), h. 15.

${ }^{29}$ Mastuki HS, dkk (ed.), Intelektualisme Pesantren ..., h. 15.
} 
Apa yang ditampilkan oleh Pesantren Soko Tunggal serta pesantren tradisional lainnya, yang tetap melestarikan model dan pendekatan dakwah dan pengajaran sebagaimana yang dikembangkan oleh Walisongo, berarti meneguhkan modertisme Islam di Indonesia. Dalam perspektif deradikalisasi, apa yang dilakukan oleh Soko Tunggal dan Gus Nuril selaku pengasuhnya, sebagai preservative de-radicalization, yaitu memelihara nilai-nilai moderatisme sebagai antisipasi terhadap model keislaman garis keras.

\section{Soko Tunggal: Mengembangkan Multikulkturalisme}

Membaca tag-line pesantren Soko Tunggal maka pikiran orang akan dengan cepat mengambil kesimpulan tentang identitas pesantren tersebut. Pesantren yang berlokasi di daerah Sedangguwo Semarang memiliki tag-line yang menarik. Tag-line tersebut berbunyi "Pondok Pesantran Soko Tunggal, Bhineka Tunggal Ika-Multi Agama". Dari tag-line tersebut orang dengan mudah menyimpulkan bahwa pesantren Soko Tunggal sangat menghargai kebhinnekaan, sebuah kesadaran bahwa Indonesia adalah sebuah Negara yang penduduknya memiliki banyak keragamaan, dari perspektif suku, agama maupun ras. Kesadaran akan keragaman ini menumbuhka rasa saling menghargai dan menghormati. Ini adalah inti dari ajaran Multikulturalisme.

Kesadaran multikultarisme tersebut tidak berhenti pada tag-line saja. Pesantren Soko Tunggal dan figur Kiai (Gus Nuril) sebagai benar-benar mewujudkan dalam dinamika kehidupan pesantren sehari-hari. Pesantren Soko Tunggal sudah sangat akrab dengan tamu-tamu dari berbagai kalangan, yang turut "Nyantri" di Soko Tunggal, baik yang ada di Semarang maupun di kota lain. Kita bisa simak penurut Gus Nuril saat ditanya (wawancara) tentang santri dan apa yang diajarkan oleh Soko Tunggal kepada mereka dalam menghadapi derasnya gerakan Islam Radikal.

“... dalam gerak amaliah kita. Ya udah di sini anak-anak ini ono anak-anak Pagar Nusa, anak-anak Laskah Merah Puth, ada Pemuda Pancasila pada minta dididik di sini kita ajarkan, mereka mendengar. Langsung aja ndak usah pakai teori enggak wong di sini sistem pondok pesantren sak umur hidup sakjelehe kok dan tidak mbayar. Dadi luluse nek wes kawin terus pindah omah itu lulus". “... tamu-tamu yang dari tokoh-tokoh nasional, tokoh-tokoh mana pun, tokoh-tokoh lintas agama, mereka mendengar langsung. Jadi tidak ada kemunafikan, ini teori yang diajarkan sementara saya berpraktek lain itu masih kemunafikan. Saya mengkoreksi itu lah, kita lihat langsung aja. Di Jakarta (Soko Tunggal Jakarta) malah pendeta-pendeta gereja ikut tinggal 
di sana, ikut puasa, ikut bangun bareng santri-santri, ikut saur meskipun mereka tidak puasa ...". ${ }^{30}$

Paparan di atas menegaskan bahwa Soko Tunggal adalah sebuah pesantren yang unik, sebuah lembaga pendidikan tradisional, namun pada saat yang sama mengajarkan nilai-nilai kosmopolitianisme, salah satunya adalah sebuah kesadaran tentang multikulturalisme. Hal ini dapat dengan mudah dijelaskan dengan memahami profil pengasuhnya, KH. Nuril Arifin, atau Gus Nuril, sebagai pendiri dan sekaligus pengasuh pesantren Soko Tunggal. KH. Nuril Arifin adalah orang yang sangat dekat figur Gus Dur atau KH. Abdurrahman Wahid, seorang tokoh pluralis dan multikulturalis. Gus Nuril adalah sahabat dan sekaligus pengagum Gus Dur, sebagaimana statemennya pada saat wawancara.

Oleh karena itu, sepeninggal Gus Dur, figur Gus Nuril menjadi “jujugan” kalangan aktivis pengusung pluralism dan multikulturalisme, khususnya di Semarang. Oleh karena itulah, tidak heran, banyak sekali tokoh-tokoh dari kalangan agama lain yang hilir mudik datang ke pesantren. Begitu sebaliknya, Gus Nuril juga tidak jarang diundang untuk memberikan ceramah di berbagai gereja untuk memaparkan tentang Islam. Ini adalah wajah dinamika multikulturalisme yang mampu mengembangkan dialog di antara para tokoh lintas agama.

Nilai-nilai multikulturalisme sangat penting sebagai bagian dari strategi deradikalisasi gerakan radikalisme. Sikap radikalisme agama, bisa muncul disebabkan oleh faktor internal dan eksternal. ${ }^{31}$ Faktor internal meliputi aspek ajaran, pengajaran dan kelembagaannya. Penekanan ajaran agama secara hitam putih akan menjadikan cara pandang yang sempit terhadap the others seperti julukan orang lain käfir, munāfiq dan lainnya. Pengajaran yang linier dan dalam ruang yang "tertutup" akan membentuk orang-orang yang egois dalam beragama, serta cara berpikir yang skriptualis dan tekstualis, dan sangat menolak tradisi lokal. Sementara dari segi kelembagaan, akan mendorong muncul sentiment keagamaan, munculnya cara pandang mayoritas dan minoritas. Sedangkan faktor eksternal menurut Mudjahirin Thohir, bisa berupa hadirnya Islam phobia, serta fenomena pembiaran terhadap kemaksiatan. Hal

30Wawancara dengan Gus Nuril, Pengasuh Pesantren Soko Tunggal, 15 November 2014.

31Mudjahirin Thohir, Multikultarisme, Agama, Budaya dan Sastra, h. 31-32. 
inilah yang kemudian melahirkan sikap heroisme keagamaan. Jihād sebagai salah model perjuangan kalangan radikalis akan menemukan momentumnya dengan faktor-faktor eksternal tersebut. Inilah signifikansi nilai-nilai multikultralisme dikembangkan. Melalui pendekatan dialog dan saling belajar memahami, maka akan mampu mengeliminir sikap radikalisme keagamaan.

\section{Anti-Radikalisme dan Resistensi Radikalisme di Pesantren Soko Tunggal}

Gus Nuril memandang gerakan radikalisme sebagai sesuatu yang sewajarnya. Sebagai sebuah paradoks, jika ada gerakan radikalisme maka ada gerakan anti radikalisme. Paradoks itu sama dengan pasangan antara siang dan malam. Selalu ada hikmahnya. Menurutnya dengan adanya kelompok-kelompok radikal, ghïrah dakwah Islam menjadi tinggi. Hal ini karena adanya kesadaran untuk membentengi jama'ah dari sikap-sikap radikal itu. Dalam ungkapannya: "Ya, kita harus terima, tetapi kita harus jaga-jaga. Ini bentuk dari cara Allah memberikan kasih sayang kepada umat Islam. Karena kalau semuanya baik, semuanya lembut, ora berjuang turu kabeh". Munculnya kajian-kajian keislaman, serta berbagai metode dakwah antara lain adalah karena upaya untuk membentengi umat dari gerakan-gerakan radikalisme itu. Sikap waspada juga dikembangkan agar gerakan radikal tidak berkembang

Secara organisatoris gerakan radikalisme juga melahirkan bentuk baru, atau paling tidak koreksi bagi organisasi-organisasi besar seperti Nahdlatul Ulama dan Muhammadiyah agar tidak kehilangan ruh keislamannya. Islam yang damai akan memancar dari perilaku tokohnya yang amanah dan tidak menebarkan kebencian. Menurutnya, "Kalau awalnya kemudian kebencian harus kita habiskan, ya sama saja kita nggak bedanya dengan kelompok radikal itu."

Namun yang menarik, radikalisme oleh Gus Nuril dipandang seperti "anak nakal". Anak nakal akan menunjukkan tingkah laku yang tidak dapat diduga dan semaunya. Anak nakal pada umumnya juga tidak akan berlangsung lama. Ada waktunya anak nakal itu akan sembuh menjadi anak sebagaimana umumnya. Para ahli psikologi menegaskan bahwa kekuatan cinta akan dapat mengubah kenakalan menjadi kesalehan. Oleh karena itu untuk menghadapi gerakan itu perlu dilakukan proses antisipasi terhadap gerakan radikalisme itu.

Gagasan genuine dari Gus Nuril mengenai gerakan radikal itulah yang kemudian melahirkan resistensi yang "spesifik Gus Nuril". Ada beberapa upaya 
resistensi yang dilakukan oleh Gus Nuril terhadap gerakan radikal. Untuk tindakan resistensi terhadap gerakan radikal sendiri Gus Nuril memandang cara Rasulullah ketika menghadapi kelompok Yahudi Khaibar sebagai analog cara memerangi radikalisme yang tepat. Memang Rosulullah kala itu memerangi kelompok Yahudi Kaibar karena Yahudi Khaibar menyerang Rasulullah. Jadi bukan Rasulullah yang menyerang Yahudi Khaibar yang ada di Madinah. Oleh karena itu dalam konteks kekinian, cara melawan kelompok radikal adalah menurut apa yang mereka lakukan. Apabila mereka keras, maka harus dibalas dengan keras. Apabila mereka mengkafir-kafirkan maka harus dibungkam. Inilah yang menurutnya sesuai adab. Berdasarkan pertimbangan tersebut, muncul beberapa upaya resistensi itu.

\section{F. Kesimpulan}

Pesantren Soko Tunggal sebagaimana pesantren pada umumnya merupakan lembaga pendidikan Islam yang beraliran moderat. Pesantren Soko Tunggal sangat menentang segala bentuk paham keagamaan yang cenderung radikal. Gerakan Islam radikal pada umumnya merupakan paham keagamaan yang berhaluan Wahabi sehingga perilaku dan pandangannya dipengaruhi oleh paham Wahabi. Radikalisme bagi kalangan pesantren merupakan akibat dari pemahaman keagamaan yang sempit dan cenderung tekstual. Sikap radikal dipengaruhi oleh fanatisme dan pembenaran terhadap pendapat sendiri yang terlalu berlebihan. Sementara bagi pesantren, keragaman merupakan takdir Tuhan yang niscaya dan tidak perlu dipertentangkan. Bagi Islam radikal, pengalaman Islam secara käffah harus ditunjukkan dengan pemberlakukan syariat Islam dalam segala tatanan kehidupan, termasuk bernegara. Untuk itu, maka Negara harus menggunakan syariat Islam sebagai dasar Negara. Sementara pesantren pada umumnya berpandangan bahwa Pancasila dan UUD 45 merupakan wujud aktual dari penegakan syariat Islam dalam konteks Negara Kesatuan Republik Indonesia.

Pesantren Soko Tunggal lebih memilih meneguhkan ajaran Islam moderat sebagai bentuk respons terhadap radikalisasi. Jalan yang dipilih tersebut dalam perspektif deradikalisasi dikenal dengan pendekatan preservative deradicalization, yaitu memelihara nilai-nilai moderatisme sebagai antisipasi terhadap model keislaman garis keras. Selain itu juga diikuti dengan pengembangan kehidupan multikultural, yaitu sebuah kesadaran akan keragaman sehingga 
dapat menumbuhkan rasa saling menghargai dan menghormati. Ini adalah inti dari ajaran Multikulturalisme. Melalui pendekatan dialog dan saling belajar memahami, Pesantren Soko Tunggal mampu mengeliminir sikap radikalisme keagamaan, terutama yang disebabkan oleh faktor eksternal. Gus Nuril memandang gerakan radikalisme sebagai sesuatu yang sewajarnya. Sebagai sebuah paradoks, jika ada gerakan radikalisme maka ada gerakan anti radikalisme.[w] 


\section{BIBLIOGRAFI}

Esposito. John L, Islam and State, New York: Syracuse University Press, 1987.

Gunaryo, Ahmad, dkk., Radikalisme Islam dan Upaya Deradikalisasi Paham Radikal, Laporan Penelitian, IAIN Walisongo, 2011.

Hanafi, Hasan, Islam in the Modern World; Tradition, Revolution and Culture, Vol. II, Cairo: Dar Kebaa Bookshop, 2000.

Hanafi, Hasan, al-Din wa al-Ṭawrah; Ușūliyyah al-Islāmiyyah, Maktabah Madbouli, t.th.

Jurgensmayer, Mark, Teror Atas Nama Tuhan, terj. Sadat Ismail, Jakarta: Nizam Press, 2002.

Mas'ud, Abdurrahman, Intelektual Pesantren: Perhelatan Agama dan Tradisi, Yogyakarta: LKiS, 2004.

Mastuki HS, dkk. (ed.), Intelektualisme Pesantren, Potret Tokoh dan Cakrawala Pemikiran di Era Pertumbuhan Pesantren. Jakarta: Diva Pustaka Jakarta, 2004.

Qardhawi, Yusuf, Islam Radikal: Analisis terhadap Radikalisme dalam Berislam dan Upaya Pemecahannya, terj. Hawin Murthado, Solo: Intermedia, 2004.

Rahmat, Imdadun, Arus Baru Islam Radikal, Transmisi Islam Timur Tengah Ke Indonesia. Jakarta: Erlangga, 2005.

Septiani, "Pelaksanaan Deradikalisasi Narapidana Terorisme di Lembaga Pemasyarakatan Kelas I Cipinang", Jurnal Kriminologi Indonesia, Vol. 7 No. I, Mei 2010.

Thohir, Mudjahirin, "Deradikalisme Keagamaan dalam Perspektif SosialBudaya" dalam Seminar Nasional Deradikalisme Agama Melalui peran Mubaligh di Jawa Tengah, Fakultas Dakwah IAIN Walisongo, 20 Juli 2011.

Thohir, Mudjahirin, Multi-Kulturalisme, Agama, Budaya dan Sastra. Semarang: Gigih Pustaka Mandiri, 2013.

Tibi, Bassam, Ancaman Fundamentalisme: Rajutan Islam Politik dan Kekacauan Dunia Baru, Yogyakarta: Tiara Wacana, 2000.

Wahid, Abdurrahman, "Pondok Pesantren Masa Depan”, dalam MarzukiWahid, dkk. (ed.), Pesantren Masa Depan, (Bandung: Pustaka Hidayah, 1999).

Walisongo, Volume 23, Nomor 1, Mei 2015 


\section{Wawancara:}

Gus Nuril, Pengasuh Pesantren Soko Tunggal, 15 November 2014. 